\title{
Who Rules the Ruler? On the Misconduct of Journal Editors
}

\author{
Aurora A. C. Teixeira • Mariana Fontes da Costa
}

(C) Springer Science+Business Media B.V. 2010

\begin{abstract}
There are very few (published) accounts of editorial misconduct, and those that do exist are almost exclusively focused on medicine-related areas. In the present article we detail a case of editorial misconduct in a rather underexplored domain, the social sciences. This case demonstrates that although legal systems provide different instruments of protection to avoid, compensate for, and punish misconduct on the part of journal editors, the social and economic power unbalance between authors and publishers suggests the importance of alternative solutions before or instead of bringing a lawsuit to court. It puts forward strong arguments in favour of the need for effective regulatory bodies so as to achieve and maintain a culture of research integrity by all involved in the process.
\end{abstract}

Keywords Scientific research $\cdot$ Ethics $\cdot$ Editorial misconduct $\cdot$ Law $\cdot$ Regulatory bodies

JEL Code $\mathrm{Z} 0 \cdot \mathrm{K} 11 \cdot \mathrm{K} 12 \cdot \mathrm{K} 42$

\section{Introduction}

“... few authors dare speak out against editors; editors can use their position and status to influence future efforts to publish. (...) editors have near absolute power and can do what they like, in part because most journal boards do not provide oversight or an appeal process." (Light and Warburton 2008: 58)

A. A. C. Teixeira

CEF.UP; Faculdade de Economia do Porto; INESC Porto; OBEGEF; Universidade do Porto, Porto, Portugal

M. F. da Costa

Faculdade de Economia do Porto; CIJE; OBEGEF; Universidade do Porto, Porto, Portugal

A. A. C. Teixeira $(\bowtie)$

Rua Dr. Roberto Frias, 4200-464 Porto, Portugal

e-mail: ateixeira@fep.up.pt 
"In what has been called the age of accountability, editors have continued to be as unaccountable as kings. But stories of editorial misconduct are growing..." (Smith 2008: BMJ Group Blogs) ${ }^{1}$

Unethical conduct in scientific works or research misconduct breeds mistrust of the academician and represents a major breach in the progress of science (Sarr and Warshaw 2006). Cossette (2004: 215) defines research misconduct as "any deliberate conduct that goes against the more or less explicit ethical rules that a community of researchers has agreed on at a specific point in time concerning the behaviour to adopt when preparing or publishing the results of a research project". Such a definition is quite broad, encompassing any attempt to mislead other people. It applies not only to researchers, but also to journal reviewers and editors to the extent that it embraces any type of conduct likely to prevent the normal course of activities associated with the production and dissemination of knowledge (Cossette 2004).

Most of the breaches of research ethics documented in the relevant literature (see Fig. 1 for the different types of research misconduct) derive from the misconduct of researchers in the form of plagiarism, data fabrication and redundant publication, and only a few (published) accounts exists on the misconduct of editors (Smith 2006; Collins et al. 2007; Light and Warburton 2008; Wager et al. 2009).

Although the real magnitude of the phenomenon of research misconduct is still not precisely known (Fox and Braxton 1994), increasingly more cases are being detected and made public (Martin et al. 2007). The public dissemination of such cases and reflection upon them have been mostly concentrated in the sciences, namely the medical sciences (e.g., Martinson et al. 2005; Titus et al. 2008), and hardly at all in the social sciences, let alone in economics and business. Regarding this latter field, the most well-known cases report to plagiarism (Enders and Hoover 2004, 2006), with a quite recent case competently described by the editors of a top journal in the area of management and innovation (Martin et al. 2007).

As a result of the (growing) concern related to the (lack of) integrity of the work submitted or published in scientific journals (both printed and online), the Committee on Publication Ethics (COPE) was established in 1997. Membership mostly includes Editorsin-Chief of scientific journals, with some publishers (e.g., Elsevier, Wiley-Blackwell, Springer, Taylor \& Francis and the BMJ Publishing Group) having signed up their entire catalogue of journal titles as COPE members. ${ }^{2}$ This organization aims at helping editors and publishers achieve and maintain a culture of research integrity based on the traditional, and perhaps outdated assumption that "...scientific community is essentially self-policing" (Martin et al. 2007: 910).

The vast majority (not to say all) of the cases of academic/research misconduct, which have been accounted for in scientific journals, involve students and authors/researchers. In a simple bibliometric exercise (performed by the authors of this article) in the Scopus database, using 'research/academic misconduct' as the search keyword, we obtained 353 items, of which 216 were articles (196 from medicine) and 16 editorials (10 from medicine). ${ }^{3}$ According to this data, research into academic misconduct is a rather recent

\footnotetext{
${ }^{1}$ In http://blogs.bmj.com/bmj/2008/10/21/richard-smith-a-ripping-yarn-of-editorial-misconduct/, accessed on 24 October 2009.

2 In http://publicationethics.org/about, accessed on 23rd October 2009.

${ }^{3}$ Search made on 22nd October 2009 in Scopus, which is considered the largest abstract and citation database of research literature and quality web sources, including nearly 18,000 peer-reviewed journals from more than 5,000 publishers (in http://info.scopus.com/overview/what/, accessed on 22nd October 2009).
} 


\begin{tabular}{|c|c|c|}
\hline Researchers & \multicolumn{2}{|c|}{ Peer reviewers and Editors } \\
\hline Fabrication of information & Unauthorized delegation of assessment & $\begin{array}{l}\text { Peer } \\
\text { reviewers }\end{array}$ \\
\hline Falsification of information & & \\
\hline Plagiarism & Deliberately biased assessment & \\
\hline Self-plagiarism & Slapdash assessment & \\
\hline "Salami-style" or fragmented publication & Breach of confidentiality & Peer \\
\hline Simultaneous multiple submissions & Unduly delayed assessment & $\begin{array}{l}\text { reviewers } \\
\text { and editors }\end{array}$ \\
\hline Abusive co-authorship & Theft of information & \\
\hline Denial of contribution & Conflict of interests & \\
\hline Unfair ordering of authors & & \\
\hline Omission of useful information & Withdrawing an article after accepting & Editors \\
\hline Quotations based on self-interest, or from & & \\
\hline Unconsulted sources & & \\
\hline Refusal to present a paper once accepted & & \\
\hline Misuse of research funding & & \\
\hline Résumé embellishment & & \\
\hline Conflict of interests & & \\
\hline
\end{tabular}

Fig. 1 Types of research misconduct. Source: Cossette (2004), Smith (2006), and Wager et al. (2009)

phenomenon, with over $70 \%$ of the items being published over the last 9 years. ${ }^{4}$ As mentioned previously, the bulk of the research in the area targets student misbehaviours (cheating, copying in exams, plagiarism, etc.), and to a lesser extent, inappropriate behaviour by researchers/authors in the form of plagiarism, data fabrication, ghost authorship, to mention but a few.

No journal articles in the gathered data were found focusing on misconduct on the part of editors. This does not mean that such behaviour is non-existent. As Smith (2006: 142) underlines "[t]here are few fully described accounts of editorial misconduct-perhaps because there is no regulatory body anywhere...".

A few cases of editorial misconduct came to light during the 2000s, albeit exclusively in medicine-related areas. Two such cases can be mentioned, an Editorial in the British Medical Journal (BMJ) in December 2004 and, more recently, in the 2008 spring issue of The Harvard Health Policy Review (Light and Warburton 2008). ${ }^{5}$

That BMJ Editorial recorded the case of an aggrieved author who complained to WAME's (World Association of Medical Editors) ethics committee after the BMJ went back on its promise to publish a paper. According to WAME's members the editor in question had behaved wrongly and the journal should honour its commitment to publish, which BMJ did.

This case was truly significant, as it may have been the first (and to the best of our knowledge, only) example of self-regulation by journal editors (Godlee 2004: 1301): "[a]n

\footnotetext{
${ }^{4}$ If we consider EBSCO database instead, including the Business Source Complete, Econlit and Academic.

5 In his book, published in 2006, 'The Trouble with Medical Journals' (published by The Royal Society of Medicine Press), Richard Smith, former editor of BMJ, dedicated a full chapter (Ch. 12) to editorial misconduct where he details a couple of nasty cases where editors have acted incorrectly.
} 
author complained, a body of editors responded, and right - as perceived by those editorswas done".

Although back in 1997 an Editorial in BMJ (Smith 1997: 201) recalled that "COPE will serve editors rather than authors or readers...", following the above-mentioned case, and based on previous work by the International Committee of Medical Journal Editors and WAME, the Committee on Publication Ethics (COPE) launched a new code of conduct for editors explicitly stating that, among other 'duties', editors should "[s]tand by decisions to publish papers unless serious problems [of authors' misconduct] are found."

As mentioned earlier, these concerns about ethical behaviours by all the players in the process of scientific research have been to a large extent situated in the medical sphere. No entities similar to WAME in role and scope exist in other scientific areas. Although COPE encompass journals of social science areas, ${ }^{6}$ and possesses procedures to handle complaints against editors, ${ }^{7}$ in the case such complain is against a non-COPE member, COPE would not consider it. This raises difficulties or even prevents that processes of potential misconduct (particularly by editors against authors in innovation studies area), ${ }^{8}$ be properly investigated and solved. Light and Warburton (2008) seem to share this view point.

Donald Light and Rebecca Warburton were involved in an intricate submission process of a paper to the Journal of Health Economics. ${ }^{9}$ The critical point here was that the paper cast doubts on the claims of a paper published earlier (2003) in the same journal, co-authored by three of the five editors of the Journal of Health Economics. Given the scepticism that Light and Warburton had in relation to the said paper, in 2004 they submitted a paper to the journal arguing that the claim was unfounded (it depended on confidential data that could not be verified and competing interests strongly influenced the study's findings). The editors of the journal agreed to publish the paper with "major modifications," and in particular they wanted to remove the "unfair claims about the motives of the ... authors." Five months after their paper was accepted, the editors still insisted on the removal of material that suggested that the results may have been influenced by competing interests. One of the editors (and co-author of the paper in question) in an email to the authors plainly asserted: "basically accept my chops on your rejoinder and get it published soon in the JHE or take your critique elsewhere". Although they considered this "ultimatum editing", Light and Warburton decided to accept under protest. In January 2005 the editors pulled all the papers out of production without giving a reason. In March 2005 the editors said they would publish the paper but only if 100 of the 132 lines in Light

\footnotetext{
${ }^{6}$ Taking as reference the distribution of journal titles by scientific area in Scopus and ISI Web of Knowledge (Journal Citation Reports 2008), according to which around 23\% of journals are from the social science areas, it is interesting to note that COPE membership in terms of journal titles represents a similar share of social science journals (Source: authors computations based on data available in http://publicationethics.org/ allmembers, accessed on 23rd October 2009).

${ }^{7}$ See http://publicationethics.org/files/u2/08_Editor_complaint.pdf, accessed on 23rd October 2009.

${ }^{8}$ Only 12 journals out of the 4755 journals which by February 2010 were members of COPE belong to the innovation studies area. These 12 journals belong to four publishers: Elsevier (Research Policy, Technology in Society, Technovation), Emerald (European Journal of Innovation Management, Journal of Knowledgebased Innovation in China, Journal of Science and Technology Policy in China), Taylor and Francis (Economics of Innovation and New Technology, Prometheus, Technology Analysis and Strategic Management) and Wiley (Journal of Product Innovation Management, R\&D Management) (Source: authors computations based on data available in http://publicationethics.org/allmembers, accessed on 23rd October 2009).

${ }^{9}$ This case is explained in detail by the authors in a paper published in The Harvard Health Policy Review (Spring, 2008), and summarized in BMJ Group Blogs by Richard Smith (A ripping yarn of editorial misconduct, October 2008).
} 
and Warburton's rejoinder were deleted. Reluctantly Light and Warburton accepted what they regarded as grossly unfair treatment. They nevertheless "searched frantically for some avenue of recourse or appeal." Professional bodies were of no avail, and "eminent editors reaffirmed that we were powerless." Eventually the paper was published in July 2005, but Light and Warburton believe that the editors of JHE have "violated ... almost every ethical standard established for editors." Although the editors would undoubtedly think otherwise, the key contribution of this case is that it shows how damaging and problematic the lack of a forum is, where authors could look for support and assistance in deciding whether (editorial) misconduct has taken place.

This article provides further insights on the matter, describing a case involving editorial misconduct in a disregarded context, the social sciences. In the next section (Section Misconduct on the Part of Journal Editors: The Facts), we present the facts. Then, in the following sections, we discuss the perspective of the editors on the issue (Section Misconduct on the Part of Journal Editors: the Editor's Perspective), as well as the neglected legal perspective (Section Misconduct on the Part of Journal Editors: A Legal Perspective) gathering some arguments challenging the traditional idea of science and scientific community as a self-regulating and self-policing body (Section Conclusion).

\section{Misconduct on the Part of Journal Editors: The Facts}

This awkward case occurred between 2007 and 2009. In September 2006 a paper was submitted to a Special Issue of the Journal1, which belongs to a large publisher. ${ }^{10}$

After the usual refereeing procedures, the paper was accepted in June 2007. As requested, the corresponding author sent the author agreement form by fax. The proofs of the paper arrived by email, from the Publisher's editing office in March 2008, and shortly afterwards, as requested, the revised proofs were sent back to that office.

It was only at the end of December 2008 that the corresponding author received a new email from the Publisher's editing office, asking to confirm whether the amendments made (in March 2008) on the proofs were correct. Upon opening the file containing the final paper, the corresponding author noted that the journal title was not correct. That same day, the corresponding author replied to the Publisher's editing office, with $\mathrm{CC}$ to the Guest Editor, informing that the corrected proofs sent wrongly identified the journal to which the article had been accepted. The response came the following day, this time from the Guest Editor with CC to the Editor-in-Chief (who happened to be the editor-in-chief of the two journals in question, as the authors were then informed). In his email, the Guest Editor stated that the Editor-in-Chief had intervened recently in the process and had informed him that several papers recommended to be published in Journall had to be included in Journal2. He then added that he would wait for the decision of the corresponding author as to whether he found this option still acceptable or not.

One point worth noting in this process is that between March 2008 (when the first proofs arrived with the correct journal title) and December 2008 (when the second proofs were received with the different journal title, Journal2), no further correspondence had been sent either by the Publisher or the editors (Guest and/or Editor-in-Chief). Hence, the authors, acting naturally on good faith, considered that their article was forthcoming in Journall, and had spread this information among their peers as such.

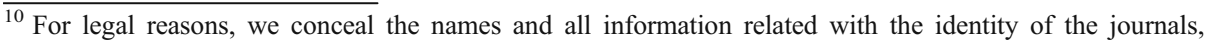
publisher, authors, editor, and guest editor.
} 
After a series of emails exchanged between the corresponding author and the Guest Editor, all with $\mathrm{CC}$ to the Editor-in-Chief, the latter decided to reply directly to the corresponding author, with the acknowledgment of the Publisher's Director, but not the Guest Editor.

In his first email, the Editor-in-Chief claimed to have sent an email to the Guest Editor (on an undisclosed date), where an explanation of the whole process of issuing special issues was detailed-most of these details, if existent, are unknown to the authors submitting to Journall or the Publisher's other journal, as they are not specified on the journals' official webpage. Moreover, he argued that based on the independent internal review process before the final stage of publication, only $x$ papers out of $y$, which have met the criteria, standard and quality of Journall, were selected for publication in the special issue. He also added that the Guest Editor agreed that the remaining papers were to be published in a special issue of Journal2. This is not exactly in accordance with the Guest Editor's view, as seen above.

Although the Editor-in-Chief, at the time of his response (3rd January 2009), had all the relevant information regarding the acceptance of the paper by the Guest Editor in June 2007, there was no subsequent retraction of this position by either the Guest Editor or the Editor-in-chief up to the date of the first (March 2008) or the second proofs (December 2008), and at no time did he concede that he or the publisher bared any responsibility. Quite the opposite, he chose to 'delegate' all responsibility on the Guest Editor's behaviour and on the lack of quality of the paper in question.

Summarizing the main facts concerning the 'case':

- The paper went through, at least so the authors were told, the usual blind refereeing process.

- They received and corrected their paper according to the referee's comments and suggestions; at no point, after revising their paper, were they told that the paper did not meet the criteria for publication in Journall; on the contrary, they received an acceptance email and the proofs for Journall.

- $\quad$ The Copyright Agreement was signed (30th June 2007) after the paper was accepted by the Guest Editor. Given that no further information was received from the Editor-inChief or the Guest Editor - it took almost a year from the Guest Editor's acceptance to the delivery of the first proofs, June 07-March 08, and from then to the second proofs, March 08-December 08, another 9 months, without any notification as to the change in Journals - the authors were in their right to assume that the Copyright Agreement was in force, that is, the paper was to be accordingly published at Journall.

- At no time (and nowhere on the Publisher's website was such information clearly stated) did the Guest Editor or the Editor-in-chief notify the authors as to the fact that the acceptance email and the proofs sent were 'NOT REAL', or that they were part of a 'mysterious', 'parallel' scheme to keep papers for publication, at their convenience, in another of the Publisher's journals rather the one to which the authors had submitted the paper and had been informed as to its acceptance.

In the authors' opinion, this case clearly represents a serious breach of professional conduct and, in the measure that they were being implicitly pressured to accept publication in Journal2 (despite having signed copyright to Journal1), there was an ethical breach as well. As authors, the editors and publishers are committed to the highest ethical standards in scholarly publishing and the absence of notification of a change in the journal in which the paper was to be published did not, according to the authors, conformed to that policy. 
The suggestion by the Editor-in-Chief that the authors' claims were intent on putting a pressure on the publisher to publish a paper, which does not meet the journal requirements was viewed by the authors as a strategy of the type "attack is the best form of defence"...

In the aftermath of the event, the corresponding author sent an email and a post letter to the Publisher's Director of Publications, who never replied. Additionally, emails detailing the whole process and asking for guidance and support were sent to renowned editors of journals dealing with ethical issues and to several editors and researchers with scientific interests in the area of management, economics and innovation. The following section details these editors' perspectives on the case described here.

\section{Misconduct on the Part of Journal Editors: The Editors' Perspective}

Given the absence of an adequate body which could receive and advise on the subject, and the lack of response from the Publisher's overall Director, in March 2009 the corresponding author contacted by email six editors of renowned international journals whose aims deal with ethics in its various dimensions, and three others from a top journal in the area of innovation studies. ${ }^{11}$ Some of the answers from these journals' corresponding editors are quoted below, which reveal that this phenomenon might be more frequent that one would expected and that editors are a kind of self-regulated yet lawless body:

"It certainly seems unusual." (Editor B)

"It looks to me as though some kind of misunderstanding ... between guest editor and editor, is at the root of your problem. The only difference between your situation and what I have seen at [journal] is that we catch this kind of thing before a manuscript gets to the page proof stage (because as editor I communicate directly with the publisher about which articles will go into production), so nothing goes into production until a regular editor has said "yes". We also have not dealt with this kind of rejection after "acceptance" by trying to publish the manuscript somewhere else without the author's permission. Rather, we simply have sent the manuscript back to the author, with an apology that the guest editor erred (for whatever reason). Anyway, that's my sense of what has happened in your case-in combination with an unfortunate lack of early communication between the editor or publisher and you regarding the problem." (Editor A)

Additional efforts by the corresponding author were undertaken by establishing contacts with some current and former editors of a top journal in the management and innovation field. These editors underlined the breach of trust and ethics that this process implied and the "moral obligation" to accept the paper in Journall.

"This is indeed a serious matter. The most problematic element is the e-mail from Guest Editor announcing that your paper has been accepted for publication in Journall without a subsequent retraction or correction. (...) Unfortunately, there is not a lot that you are likely to be able to do about this. In principle there appear to be

\footnotetext{
${ }^{11}$ From the nine editors contacted six responded. To maintain confidentiality, they are here identified with letters (A to I), attributed in a randomly way.
} 
two breaches of 'contract' - one the notification from Guest Editor which would likely be found not to be a contract because as he observes his labour was voluntary and the other in the acceptance of the copyright assignment form in June where you clearly state the journal which you are giving your paper to. Redress of these contractual matters through a legal forum is problematic in practice.

(...) the publisher is committed to the highest ethical standards in scholarly publishing and the absence of notification of a change in the journal in which your paper is to be published does not conform to that policy.

You are very clearly justified to regard this as a serious breach of professional behaviour and, to the extent, that you are being implicitly pressured into accepting publication with the Journal2 or are actually published there (despite your assignment of copyright to Journall there is an ethical breach as well.” (Editor G)

“... it would seem that you have been treated quite extraordinarily. You agreed with the Guest Editor, [name], to submit a paper to a special issue of the Journall. Your paper was submitted and accepted on this basis. In moral and perhaps also legal terms, you have a contract for your paper to be published in Journall.

Occasionally, a paper may be switched from one journal to another. However, to do so requires the express agreement of all those concerned - the editor of the first journal, the editor of the second journal, and of course the author. In this case, a due process for such a transfer does not appear to have been gone through. First of all, the managing editor of the first journal also happened to be the managing editor of the second journal. If I had been in such a position, I would have deemed this a potential conflict of interest, and asked two independent persons to make such a decision on behalf of the two journals involved. Secondly, at no point was your permission sought to effect such a transfer, and you only spotted it when sent the proofs. I find this completely inexplicable.

You could certainly stress the point ... about the transfer of your paper having not gone through due process, and that in recognition of this, the Publisher now have a moral obligation to accept the paper in Journall." (Editor I)

Albeit the seriousness and bizarre character of the situation, some of the editors recognized that this sort of editorial misconduct is (unfortunately) not as sporadic as one would think initially.

"I've encountered numerous cases of misconduct by journals and I found that there is not much one can do about it." (Editor D)

"Unfortunately this sort of thing happens not infrequently with that Publisher's journals. (...) It's happened to me before, though not so negatively as in your case; the more serious consequence was a paper which went 'missing' for about 5 years after acceptance." (Editor $\mathbf{H})$

Almost all the editors contacted, both from the Ethics-related journals and from the top journal in the innovation area, agreed that there was not much the authors could do in this situation as "[t]here is no mechanism to discipline a journal." (Editor D).

Authors, as one of the Editors from the top journal in innovation recognizes, are therefore left on their own as the ruler - the journal's editor-is not ruled, and as such does not have to respond for his/her misconduct. In general, the editors contacted did not acknowledge any body to which authors could turn in situations of (potential) editorial misconduct.

"I do not know of any international standards body or anything else like that to which you could in some way appeal this outcome." (Editor A) 
At the end of the day, one point was consensual among the editors: authors would seldom win "the battle". Therefore, some of the 'solutions' proposed were:

"... to withdraw the paper completely, and submit it to another journal, having wasted a lot of time." (Editor I)

"The safer thing to do is to have nothing to do with any Publisher journals out of this 'stable', whether or not ISI indexes them." (Editor H)

"Short of attempting a costly and probably futile lawsuit, I suspect your only options are to either (a) publish in it Journal2, (b) ask that it be published in future regular issue of Journall, as a regular manuscript, or (c) withdraw the paper from consideration, and submit it somewhere else." (Editor A)

"My best suggestion is that you refer to the Committee on Publication Ethics (COPE)." (Editor B)

Symptomatic as it might seem, the Publisher's journals are not members of COPE...

\section{Misconduct on the Part of Journal Editors: A Legal Perspective}

According to Article 2(1) of the Berne Convention, all productions in the literary, scientific and artistic domain, independently of the mode or form of its expression, are legally qualified as "literary and artistic works".

On the same matter, the Copyright, Designs and Patents Act 1988 states, in Section 3(1), that the legal term "literary work" includes any work which is written, spoken or sung, with the exception of dramatic or musical works. ${ }^{12}$

In order for a literary work to be protected as copyright in the United Kingdom it must be original $^{13}$ and it must also be recorded, in writing or otherwise. ${ }^{14}$ The requirement for permanent fixation of the literary work is also foreseen in the Berne Convention, in Article 2(2), although the demand for its enforcement is left to the discretionary decision of each Member State.

Not coincidental with the common law perspective of copyright, law jurisdictions of continental Europe (closer to the French droit d'auteur) underline the nature of the work as a personal creation of the author. As a form of self-expression, the work reflects on the personal reputation and integrity of the author. Therefore, he/she ought to be entitled to control every facet of that work (Phillips and Firth 1995: 241). Literary works are protected as oeuvres de l'esprit, ${ }^{15}$ which means they are protected mainly because they are a work of the spirit of their authors.

Considering that the paper referred to in Sections Misconduct on the Part of Journal Editors: The Facts and Misconduct on the Part of Journal Editors: The Editors' Perspective of the present article constitutes a written scientific production, it falls under the category of "literary work", both according to the definition given by the Copyright, Designs and Patents Act 1988 and by the Berne Convention.

\footnotetext{
12 On the notion of "literary work", see Cornish and Llewelyn (2007: 421-425).

13 Section 1(1) of the Copyright, Designs and Patents Act 1988.

${ }^{14}$ Section 3(2) of the Copyright, Designs and Patents Act 1988.

${ }^{15}$ The French Code de la Propriété Intellectuelle refers, in several articles, to the expression 'oeuvres de l' esprit" to identify the object of protection in intellectual property law. See, for example, Article L112-1: "Les dispositions du présent code protègent les droits des auteurs sur toutes les oeuvres de l'esprit, quels qu'en soient le genre, la forme d'expression, le mérite ou la destination" (The legal provisions of the present code protect copyright of all works of spirit, whatever may be the mode or form of its expression, the merit or the intended purpose - translation by the authors).
} 
It may also be considered a scientific oeuvre de l'esprit, since it was created by the mind of the authors, as a result of their previous investigations and has therefore, in the expression of Stamatoudi (2002: 64), their "personal imprint".

In addition, the referred paper is also an original work-fact that was never questioned by the Guest Editor or the Editor-in-Chief - and obeys the requirement for permanent fixation.

Bearing in mind all of the above-mentioned aspects, the first important legal premise to consider in the analysis of the situation described in Sections Misconduct on the Part of Journal Editors: The Facts and Misconduct on the Part of Journal Editors: The Editors' Perspective is that the paper submitted to publication is object of copyright protection, both under the common law and the civil law jurisdictions.

Two main questions arise from the situation under analysis: the first refers to the boundaries of the authors' right to decide whether and where to publish their literary works, and the second to whether and when the publisher becomes legally bound to publish the literary work.

With regard to the first question, it is important to remember that the authors had submitted their paper to a special issue of a certain journal, Journall. After the refereeing procedures, the paper was accepted by the Guest Editor for publication in that particular journal, which is identified in the Author Agreement. However, when the second proofs arrived, the authors noticed that the journal title did not correspond to the journal to which they had submitted the paper. Only after asking for clarification, did it become clear to the authors that the Publisher intended to publish the paper in a different journal (Journal2).

This matter relates to the core of copyright protection: the author's exclusive right of disclosure. ${ }^{16}$

As stated in Article 9(1) of the Berne Convention "Authors of literary and artistic works protected by this Convention shall have the exclusive right of authorizing the reproduction of these works, in any manner or form". Consequently, in order for a publisher to publish a work he/she must have an agreement with the author, granting him/her an assignment or licence to publish. In some countries, for example Portugal, ${ }^{17}$ that assignment must contain specifically the authorized form of disclosure, publication and utilization, as well as the conditions of time, place and retribution.

It has been discussed whether the right of disclosure should or should not be considered a moral right of the author. This question is usually discussed in the civil law jurisdictions, where the protection of the author's moral rights is usually viewed as a consequence of the special relationship between the author and his/her work. ${ }^{18}$ Following the opinion of

\footnotetext{
${ }^{16}$ The right of disclosure is here considered in a broad sense, as the exclusive right of the authors to bring their work to the public's knowledge, in any manner or form. In this broader sense, the right of disclosure includes in its ratio also the right to publish, described as the authors' exclusive right to reproduce or allow the reproduction of their work.

${ }^{17}$ Artigo $41 .^{\circ}$, n. ${ }^{\circ} 3$ Código do Direito de Autor e dos Direitos Conexos.

${ }^{18}$ In this context, it is interesting to remember the words of the French Court in the case Camoin et Syndicat de la Propriété Artistique c. Francis Carco, Aubry, Belattre et Zborowski (Trib.Civ. de la Seine, 15 November 1927, DP. 1928.2.89, confirmed in Carco et autres c. Camoin et Syndicat de la Propriété Artistique, Cour d'Appel de Paris, 6 March 1931, DP. 1931.2.88). This case dates back to 1927. Camoin was a pictorial artist. One night of 1914 he decided to rip and throw away some of his paintings. However, the next morning, a rag picker found the paintings and sold them to an art collector. Over the years, they were sold several times, until, 11 years later, Camoin discovered that these works had been put up for sale. Camoin then objected in court against the disclosure of these works without his consent. The court decided that, in this particular case, the author's right to disclosure (droit de divulgation) should prevail over the right of property of the paintings. In the courts' words, by disclosing his works against his will, the defendants had violated the author's personality, since the work of an author is "the expression of his thought, his personality, his talent, his art, and, in philosophical terms, of his individual self" ("[L]'expression de sa pensée, de sa personnalité, de son talent, de son art, et l'on pourrait dire en termes de philosophie, son moi individuel") - for a more developed description of this case, see Teilmann (2005: 78-79).
} 
Ascensão (2008: 157-158), the right of disclosure presents apparent similarities with moral rights, especially with the moral right of authors to never disclose their work. In fact, one is tempted to say that both rights represent the two sides of a coin. However, this is not the case. Moral rights are characterized by their inalienability. On the contrary, the author can transfer the right of disclosure to a third party and it is, therefore, an economic right.

By signing the Author Agreement, the authors gave permission to publish the paper in the journal specifically identified in the Agreement. Therefore, the publisher was forbidden by law to publish the paper in another journal. And we believe the answer to be the same, even if the authors did return the second proofs with the amendments. In this case, considering the written form of the assignment to be only an "ad probationem" formality (which is not unanimous), the publisher would still have to prove that by returning the corrected proofs, the authors implicitly agreed with the change in the journal in which the paper was to be published.

In cases where the journal for publication is changed without obtaining the consent of the authors, the publisher would have violated the Author Agreement as well as the exclusive right of the authors to decide whether or not to publish their work. Fortunately, the authors became aware of the intended conduct in time and were able to avoid the infringement of their right.

It is also questionable if the publication of the work in the different journal could be considered a violation of the authors' right to the integrity of the work. The right to the integrity of the work is a moral right, recognized both by the civil law and the common law jurisdictions and by the Berne Convention. ${ }^{19}$

In the United Kingdom, the right of integrity is stated in Section 80 of the Copyright, Designs and Patents Act 1988, under the heading "Right to object to derogatory treatment of work". In order for authors to invoke this moral right, they have to prove that their work was subjected to a "treatment" in the sense given by Section 80 (2a) of the Copyright, Designs and Patents Act 1988 and that this treatment is "derogatory" in the sense given by Section $80(2 b)$ of the same Act. ${ }^{20}$

In the civil law jurisdictions, as well as in the Berne Convention, the notion of "treatment" is usually broader and the focus is put mainly on the damages caused by the action to the honour or reputation of the author. Authors may invoke their moral right to the integrity of the work whenever a third party's action in relation to the work is or is likely to be damaging to their honour or reputation.

Considering the right of integrity under the United Kingdom's jurisdiction, Phillips and Firth (1995: 250) mention that "it is unlikely that placing a work in an inappropriate context constitutes "treatment"". Focusing on the case under analysis, it is also unlikely that the publication of the paper in a different, yet still scientific, journal would, per se, imply any damage to the honour or reputation of the authors. Unless special circumstances indicated a different outcome, this case apparently does not implicate a violation of the authors' right to the integrity of the work.

However, the authors had already rightly diffused through their peers that the paper would be published in the journal it was submitted to, Journall. Therefore, the publication of the paper in a different journal (namely, Journal2) could have raised problems for the authors in terms of academic reputation. Nevertheless, these problems would not have been created by an offence to the integrity of the work, but by non-compliance with the Author Agreement on the part of the publisher.

\footnotetext{
${ }^{19}$ Article 6bis(1) of the Berne Convention states: "Independently of the author's economic rights, and even after the transfer of the said rights, the author shall have the right to claim authorship of the work and to object to any distortion, mutilation or other modification of, or other derogatory action in relation to, the said work, which would be prejudicial to his honor or reputation".

${ }^{20}$ See Cornish and Llewelyn (2007: 492-497).
} 
This reference to possible non-compliance with the Author Agreement by the publisher brings us to the second question posed above. Was the publisher legally bound to publish the paper in the journal identified in the Author Agreement?

Contracts are a typical form of exercising exclusive economic copyrights and among these contracts, the publishing contract is undoubtedly "the prototype of copyright contracts" (expression taken from Ficsor 2008: 51).

The main characteristic of the publishing contract is that the publisher is given not only the power to publish the author's work, but also has the legal obligation to do so. Publishing the work is an essential element of the contract. ${ }^{21}$

The publishing contract is based on a bilateral commitment between authors and publishers: authors contribute with the results of their intellectual activity and are usually bound not to publish that work elsewhere and to abide by the journal requirements; publishers commit to publishing the papers in the agreed terms.

As has been said several times before, the authors of the paper referred to in Sections Misconduct on the Part of Journal Editors: The Facts and Misconduct on the Part of Journal Editors: The Editors' Perspective of this article, after the refereeing procedure and the acceptance of their paper by the Guest Editor, signed a document entitled "Author Agreement". This document states that the authors assign the publisher the copyright of that particular paper to be published in the identified journal (Journall) and that the publisher undertakes to publish the paper in that journal.

However, the document also states that the Agreement only comes into effect if the paper is accepted, by the publisher, for publication. This particular clause is the key to decide whether or not the publisher was bound to publish the authors' paper.

By analyzing the above-mentioned clause, the first conclusion one can draw is that the parties consider they have reached an agreement, which automatically comes into effect once the article is accepted for publication. However, this acceptance for publication is likely to raise qualification problems, if we examine the clause under the civil law and the common law jurisdictions. ${ }^{22}$

Under the common law jurisdiction, this clause is likely to be considered a contingent condition precedent. ${ }^{23}$ This means that the contract has already been concluded, but it only becomes binding if and when the paper is accepted for publication.

The specificity of this condition is that its fulfilment rests on the decision of one of the parties, in this case, the publisher. This clause is very similar to the "subject to satisfaction" condition (Peel 2007: 70-71), wherein the contract only comes into effect when one of the parties informs the other that they are satisfied with the subject-matter or any other aspects relating to the other's performance.

Similarly to the "condition of satisfaction", it seems reasonable to conclude that the condition here analyzed occurs if and when the publisher informs the authors of his/her decision to publish the paper. Quoting Treitel (writing about communication on "subject to satisfaction" conditions-2003: 64, footnote 66. Also in the twelfth edition, by Peel (2007: 70, footnote 575): "For the requirement of communication (...); the requirement may be satisfied by conduct from which satisfaction can be inferred".

Applying the exact same reasoning to this case, the requirement for communication of the decision to publish the paper may be satisfied by conduct from which the decision to publish can be inferred. This requirement was fulfilled, if not sooner (which would be the case if the Guest Editor had the legal power to bind the publisher by his initial decision to accept the paper

\footnotetext{
${ }^{21}$ On the Italian contratto di edizione per le stampe, see Sanctis and Fabiani (2007).

22 The solutions presented below are representative of the common core principles of each main European legal family, but do not take into consideration the specificities of individual countries' legislation.

${ }^{23}$ For further information on this subject, see Peel (2007: 67-72).
} 
for publication) when the publisher sent the authors the first proofs of the article. Therefore, considering the clause a contingent condition precedent, the contract came into effect at least in March 2008, when the authors received an email with the first proofs.

Under the civil law jurisdictions, the qualification of the clause "the Agreement only comes into effect if the paper is accepted for publication" as a contingent condition may raise more difficulties than in the common law jurisdictions, where the legal concept of condition has a broader sense. One possible problem is that several countries refuse the validity of a condition based on an event, whose occurrence relies solely on the debtor's discretion. ${ }^{24}$ Moreover, the event consists of the acceptance, by the publisher, of his main obligation.

If the clause is considered to be a contingent condition, the reasoning presented for the common law jurisdictions is also valid and applies fully here. Another solution is to consider the Author Agreement as an Option Contract. ${ }^{25}$ In this case, the authors are already bound to the conclusion of the contract, with the contents of the Author Agreement, but the publisher maintains full freedom to decide whether or not to conclude the contract in question. The contract is concluded by a unilateral declaration of will by the publisher.

Independently of the clause being qualified as a condition or as an indicator of an Option Contract, the solution is identical. The declaration of will may be expressed by conduct, as long as the conduct is accompanied by the intention of becoming legally bounded. ${ }^{26}$ In the case under analysis, the publisher's conduct of sending the proofs will be considered a declaration of the will to conclude the contract if it is accompanied by the intention to conclude the contract.

However, this intention is ascertained, in most European legal systems, in accordance with the objective principle, which means that an apparent intention is sufficient if it is enough to induce a reasonable person to believe that the intention exists ${ }^{27}$ (as long as the receivers themselves also believe that the intention exists). ${ }^{28}$

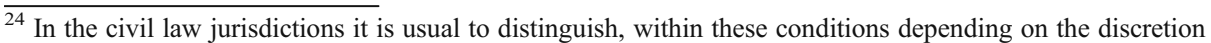
of one of the contract parties (called "condition potestative" in France and "condizione potestativa" in Italy), between those in which the fulfillment of the condition depends purely on the discretion of the debtor (a simple "because I want to") and those in which the fulfillment of the condition depends on a will influenced by outside interests, objectively appraised. Only the first type of conditions is usually considered void. See, for the French legal system, Carbonnier (2000: 263-264), for the Italian legal system, Roppo (2001: 616$619)$ and for the Portuguese legal system, Pinto (2005: 565-566).

${ }^{25}$ Also alerting to the possible difficulty in distinguishing between a contingent condition precedent $a$ parte debitoris and an option contract, Roppo (2001: 618): "Immaginiamo adesso che la condizione sia applicata a una compravendita, i cui effetti sono subordinati a che l'alienante dica che vuole alienare. Un contratto del genere non fa scandalo, perché corrisponde in sostanza a un'opzione di vendita".

${ }^{26}$ All legal systems of the European Union recognize the validity of acceptance by conduct. See, for all, Lando and Beale (2000: 169-170).

${ }^{27}$ Referring to the objective nature of the "Test of Intention", in England, see Beatson (2002: 31). Also addressing this issue, in Germany, Fikentscher and Heinemann (2006: 91-97) and, with more details, Brehmer (1992). In the context of the formation of contracts in Italy, Roppo describes the notion of "conclusive behaviour" (comportamenti concludenti) as an active behaviour which, in the given context, has the semantic meaning that the party wants to enter the contract (Roppo 2001: 199-201). As an exception to the objective principle, the French legal system adopts a subjective perspective, stating that the person will only be bound if it is his real intention to be bound. However, a party alleging, in this context, that they had no intention to be bound must make this allegation plausible. This is probably why Carbonnier states that, even though in France the declaration of will only has value if it is consistent with the inmost will (subjective principle) and in Germany the declaration of will is the essence of the contractual consent (objective principle), it is important not to exaggerate the difference of consequences on a practical level (Carbonnier 2000: 91)

${ }^{28}$ The objective principle was also adopted by the Principles of European Contract Law, in Article 2: 102, which states that: "The intention of a party to be legally bound by contract is to be determined from the party's statements or conduct as they were reasonably understood by the other party" (Lando and Beale 2000: 143).
} 
In this case, by sending the proofs, the publisher induced the authors to believe the paper had been accepted for publication and that the publishing contract was, therefore, effective. Independently of the publisher's real intentions (which we cannot have access to), the act of sending the proofs of publication to the authors, more than 6 months after the signature of the Author Agreement, is sufficient to lead a reasonable person to believe the paper was accepted to be published. ${ }^{29}$

The answer to the second question is, consequently, likely to be affirmative, in the sense that the publisher was bounded by contract to publish the paper in the journal identified in the Author Agreement.

Admitting the existence of the contract, the publisher committed a breach of contract, by refusing to publish the authors' paper in the identified journal without a lawful excuse.

Given the importance of contracts as a privileged means to regulate and promote individual interests, every jurisdiction contains legal provisions concerning the protection of a victim of breach of contract. However, the majority of these remedies requires that the injured party bring a lawsuit to court. ${ }^{30}$ And even though there is a growing effort to ensure every person has access to courts and consequently to justice, a lawsuit against a publisher, in order to sue for breach of a publishing contract, raises particularly difficult problems for the author. ${ }^{31}$

Firstly, when involving scientific journals and academic authors, there is a strong possibility that the case will have connections to more than one country (for example, if the author has a certain nationality or place of residence and the publisher's headquarters are located in a different country). In this scenario and applying international private law rules, it is very likely that the author will have to bring the suit to a court in the country of the publisher's headquarters. This will not only significantly increase the legal costs of the action, but also those related with legal counselling.

Secondly, a considerable amount of scientific articles concern research and subjects related to a specific moment in time and the interest of their publication is not compatible with the usual delays in court decisions. For that reason, even if we consider the possibility of the court recognizing the author's right to the specific performance of the contract (which, in the case under analysis, would mean that the publisher would be forced by the court to publish the paper), ${ }^{32}$ that decision may come too late to protect the author's interests.

Thirdly, when considering a suit for damages, it is very difficult to determine and prove the amount of damages suffered by the authors with the breach of the publishing contract, since the publication was not remunerated and the publisher did not obtain any profit from the breach. ${ }^{33}$

\footnotetext{
${ }^{29}$ Moreover, the elaboration of the first proofs by the publisher can be interpreted as an act of performance of the contract, since it is already part of the process to publish the paper. Roppo qualifies this performance as being part of the negozi di attuazione, that is, particularly contracts in which the will to contract is revealed by the beginning of performance (Roppo 2001: 200).

${ }^{30}$ For a comparative analysis on the remedies for breach of contract, see Zweigert and Kötz (1998: 470-515) and Laithier (2004).

${ }^{31}$ One important problem, not directly related to the legal systems, is the eventual fear of the author to be blacklisted and prevented from publishing his future works. Writing about this problem in relation to freelance authors, see D'Agostino (2005: 167)

32 The possibility of the author being granted specific performance in this case is not unanimous, even if we consider only the common law jurisdiction. On this subject and mentioning two cases with opposite decisions (one recognizing specific performance of a contract to publish a piece of music and another denying specific performance of a contract to publish a book on the grounds that it would require continued co-operation between the publisher and the author), see Peel (2007: 1114, footnote 210).

${ }^{33}$ However, it is important to note that along with the compensation for possible financial damages, the authors could eventually demand damages for injury to their academic reputation (Beatson 2002: 594-595).
} 
For all the above-mentioned reasons, although legal systems provide different instruments of protection to avoid, compensate for and punish misconduct on the part of journal editors, the social and economic power unbalance between authors and publishers suggests the importance of alternative solutions before or instead of pursuing a lawsuit. This is precisely why Associations like WAME and COPE are valuable and similar entities should be established in other scientific areas beside the medical ones.

Journals should provide the authors with general rules on appeals against editorial decisions and, in an ideal and transparent process, they should also consider the possibility of resorting to an impartial third party to evaluate the disagreement. ${ }^{34}$ It is therefore essential to provide authors of academic papers with an impartial forum where they can, in a feasible way, present their complaints against editors and ultimately be compensated in the case of editorial misconduct.

The possibility of authors having an impartial forum they can turn to should be based first and foremost on a voluntary attitude on behalf of the Journal (i.e., the publisher), either by creating an internal process of appeal and adhering to external self-regulating bodies, such as COPE. Nevertheless, it is important to stress that COPE does not file lawsuits, it only issues recommendations (Godlee 2004).

Specifically, in the case of a complaint against an editor, COPE suggests the following procedure (presented here in very concisely way). ${ }^{35}$ If the Chair of COPE (or the ViceChair, in case the Chair of COPE belongs to the same publishing group as the complainant) and at least one member of the COPE Council decide the case deserves further investigation, they will refer it to a COPE sub-committee. The sub-committee (which comprises the Chair and three other Council Members, two of whom are not editors and none of them work for the same publishing group as the complainant) will then take the case under consideration. If the sub-committee considers that a breach of COPE's code of conduct has taken place, it presents a report to the COPE Council and recommends a course of action. The Council will then consider the case and determine its final recommendations, which may include: 1) editor should apologise to complainant; 2) editor publishes a statement from COPE in the Journal; 3) Journal/Editor agrees to improve procedure; 4) editor resigns from COPE membership for a period of time or 5) any other action which the COPE Council considers appropriate given the circumstances of the case.

It is worth noting that the publisher is ultimately accountable as 'a last resort' for editors' misconduct and, as such, has increased responsibility for taking action to compensate authors. In a somewhat drastic yet straightforward manner, Karlberg (2007: 50) argues that when misconduct is proven "...[a] serious publisher can apply sanctions to misbehaving editors simply by sacking them.”

As seen in the cases described in Section Introduction, most of the complaints of editorial misconduct relate to unjustified refusal to publish, unjustified delays in publication or unjustified demand for alterations. In all of these situations, the most appropriate action is the effective publication of the article. Therefore, specific actions, namely the due publication of a paper in a specific Journal, should be considered a priority, whenever possible and adequate.

\footnotetext{
${ }_{34}$ These ideas are also expressed in the Summary of Listserve's discussion on Post-Acceptance Rejection of a Manuscript, written by Michael Callaham, in http://www.wame.org/ethics-resources/post-acceptancerejection-of-a-manuscript, accessed on 24 October 2009.

${ }^{35}$ In http://publicationethics.org/files/u2/New_Code.pdf and http://publicationethics.org/files/u2/08_Editor_ complaint.pdf, accessed on 22 June 2010.
} 
The focus of the decision for an internal appeal or an impartial committee should not target the editor's punishment as such, but rather the author's rights. The criterion should be to follow the course of action which most adequately restores the injured party (in this case, the author) to the situation he/she would have been in had the misconduct not taken place. Only when this is not possible (or cumulatively, when appropriate) should the policy board resort to other measures, in order to attenuate the effects of the misconduct, such as the above-mentioned published statement in the Journal or written apology.

\section{Conclusions}

"If editorial freedom is thought to mean that editors should be free to do whatever they want, then it is a myth. (...) Perhaps because of the power of the myth of editorial freedom editors are often much less accountable than other professionals, and there are many examples of editors abusing their positions without any retribution." (Smith 2006: 139)

Most of the breaches of research ethics documented in the relevant literature derive from researchers' misconduct in the form of plagiarism, data fabrication and redundant publication. Very few (published) accounts exist on editorial misconduct, and (up to the present date) are exclusively situated in medicine-related areas. Such a lack of accountability is to a large extent explained by the absence of a regulatory body.

Given concerns (mainly by editors) with the increasing lack of integrity of the work submitted or published in scientific journals (both printed and online), some organizations, most notably, the World Association of Medical Editors (WAME) and the Committee on Publication Ethics (COPE), were established in the 1990s. These bodies were mainly directed at helping editors and publishers to achieve and maintain a culture of research integrity based, nevertheless, on the assumption of a self-policing scientific community (Martin et al. 2007).

The concerns and public case discussion about ethical behaviours in the process of scientific research have been almost exclusively centred on the medical sphere. Bodies comparable to WAME in role and scope do not exist in other scientific areas. Although COPE includes already a considerable number of journals from the social sciences domain, the number of publishers that have signed up their entire catalogue of journal titles as COPE members is still meagre. Specifically, in innovation studies area only twelve journals from four publishers (Elsevier, Emerald, Taylor \& Francis Wiley-Blackwell) are, at the present moment, members of COPE. This raises difficulties or even prevents that processes of potential misconduct, namely by editors against authors, and particularly in areas outside the medical sciences, be properly investigated and solved (Light and Warburton 2008).

This article presented detailed evidence on a case involving editorial misconduct in the domain of the social sciences, more exactly in innovation studies area. Beside the facts concerning the misconduct process, it provided a legal perspective on the phenomenon.

We can from this particular case conclude that although legal systems provide different instruments of protection to avoid, compensate for and punish misconduct on the part of journal editors, the social and economic power unbalance between authors and editors suggests the importance of alternative solutions before or instead of bringing a lawsuit to court. Journals should provide the authors with general rules on appeals against editorial 
decisions and, in an ideal and transparent process, they should also consider the possibility of resorting to an impartial third party to evaluate the disagreement. Whether in the case of an internal appeal or an external committee, the focus should be on finding and recommending the most suitable course of action to protect the author against the damages caused by the misconduct. Whenever possible and appropriate, such action should consist of specific performance. Associations such as COPE already provide impartial forums on the matter of editors' misconduct and for that are worthy of praise. Their example should be followed by editors of journals in all scientific areas.

Acknowledgements We would like to express our most sincere gratitude to all the journal editors who thoroughly analyzed the case described here and kindly share their views on the matters and suggested some actions. We also thank the two referees for their comments and pertinent suggestions.

Conflicts of interest The corresponding author of the present article was one of the three complainant co-authors.

\section{References}

Ascensão, J. O. (2008). Direito Civil. Direito de Autor e Direitos Conexos, reprint. Coimbra: Coimbra Editora.

Beatson, J. (2002). Anson's law of contract (28th ed.). Oxford: Oxford University Press.

Brehmer, N. (1992). Wille und Erklärung. Zu Geltungsgrund, Tatbestand und Zurechnung der Willenserklärung, Baden-Baden, Deutschland: Nomos Verlagsgesellschaft.

Carbonnier, J. (2000). Droit Civil. 4. Les obligations, Paris, France: Presses Universitaires de France.

Collins, A., Judge, G., \& Rickman, N. (2007). On the economics of plagiarism. European Journal of Law and Economics, 24(2), 93-107.

Cornish, W., \& Llewelyn, D. (2007). Intellectual property: Patents, copyright, trade marks and allied rights (6th ed.). London: Thomson Sweet \& Maxwell.

Cossette, P. (2004). Research integrity: and exploratory survey of administrative science faculties. Journal of Business Ethics, 49, 213-234.

D'Agostino, G. (2005). Freelance authors for free: Globalisation of publishing, convergence of copyright contracts and divergence of judicial reasoning. In F. Macmillan (Ed.), New directions in copyright law, vol. 1 (pp. 166-215). Cheltenham: Edward Elgar.

Enders, W., \& Hoover, G. A. (2004). Whose line is it? Plagiarism in economics. Journal of Economic Literature, 42, 487-493.

Enders, W., \& Hoover, G. (2006). Plagiarism in the economics profession: a survey. Challenge, 49, 92-107.

Ficsor, M. (2008). Teaching copyright and related rights. In Y. Takagi, L. Allman, \& M. Sinjela (Eds.), Teaching of intellectual property. Principles and methods (pp. 33-62). Cambridge: WIPO Academy, Cambridge University Press.

Fikentscher, W., \& Heinemann, A. (2006). Schuldrecht (10th ed.). Berlin: De Gruyter Recht.

Fox, M. F., \& Braxton, J. M. (1994). Misconduct and social control in science: issues, problems, solutions. The Journal of Higher Education, 65, 373-383.

Godlee, F. (2004). Editorial. Dealing with editorial misconduct. New code of conduct for editors is a first step in self regulation. British Medical Journal, 329, 1301-1302.

Karlberg, B. (2007). Publication of chemical research: do we need ethical standards? Accreditation and Quality Assurance, 12, 49-50.

Laithier, Y-M. (2004). Étude comparative des sanctions de l'inexécution du contrat, Paris: L.G.D.J.

Lando, O., \& Beale, H. (2000). Principles of European Contract Law, Parts I and II, prepared by The Commission of European Contract Law. The Hague: Kluwer Law International.

Light, D., \& Warburton, R. (2008). In focus: "ethical standards for healthcare journal editors: a case report and recommendations". Harvard Health Policy Review, 9(1), 58-67.

Martin, B., et al. (2007). Keeping plagiarism at bay—a salutary tale. Research Policy, 36, 905-911.

Martinson, B. C., Anderson, M. S., \& de Vries, R. (2005). Scientists behaving badly. Nature, 435, 737-738.

Peel, E. (2007). Treitel on The Law of Contract (12th ed.). London: Sweet \& Maxwell.

Phillips, J., \& Firth, A. (1995). Introduction to Intellectual Property Law (3rd ed.). London: Butterworths. 
Pinto, C. M. (2005). In A. P. Monteiro \& P. M. Pinto (Eds.), Teoria geral do direito civil (4th ed.). Coimbra: Coimbra Editora.

Roppo, V. (2001). Il contratto, Trattato di Diritto Privato a cura di Giovanni Iudica e Paolo Zatti. Milano: Dott. A. Giuffrè Editore.

Sanctis, V., \& Fabiani, M. (2007). I contratti di diritto di autore (2nd ed.). Milano: Dott. A. Giuffrè Editore.

Sarr, M., \& Warshaw, A. (2006). Ethical misconduct in publishing: the editors' perspective. World Journal of Surgery, 30(8), 1374-1376.

Smith, R. (2006). The trouble with medical journals. Journal of the Royal Society of Medicine, 99, 115-119.

Smith, R. (2008). A ripping yarn of editorial misconduct. BMJ Group Blogs Tuesday, October 21st, 2008, in http://blogs.bmj.com/bmj/2008/10/21/richard-smith-a-ripping-yarn-of-editorial-misconduct/. Accessed 24 Oct 2009.

Smith, R. (1997). Editorials: Misconduct in research: editors respond. The Committee on Publication Ethics (COPE) is formed. British Medical Journal, 315, 201-202.

Stamatoudi, I. (2002). Copyright and multimedia products. A comparative analysis. Cambridge: Cambridge University Press.

Teilmann, S. (2005). Justifications for copyright: The evolution of le droit moral. In F. Macmillan (Ed.), New directions in copyright law, vol. 1 (Vol. 1, pp. 73-87). Cheltenham: Edward Elgar.

Titus, S. L., Wells, J. A., \& Rhoades, L. J. (2008). Repairing research integrity. Nature, 453, 980-982.

Treitel, G. (2003). Treitel on The Law of Contract (11th ed.). London: Thomson Sweet \& Maxwell.

Wager, E., Fiack, S., Graf, C., Robinson, A., \& Rowlands, I. (2009). Science journal editors' views on publication ethics: results of an international survey. Journal of Medical Ethics, 35, 348-353.

Zweigert, K., \& Kötz, H. (1998). An introduction to comparative law, translated by Tony Weir (3rd ed.). Oxford: Oxford University Press. 